\title{
Evaluation of uric acid levels as antioxidant during normal pregnancy and pregnancy with complication (diabetes and hypertension)
}

\author{
Habiba Khudair Abd Al-Sadda ${ }^{1}$, Moafaq Sachit Samir ${ }^{2}$, Ahmed Abdul-Jabbar Suleiman ${ }^{3}$, Yusra Sebri Abdul-Saheb ${ }^{4}$
}

\begin{abstract}
The uric acid is a waste product of the living cell, produced by xanthine oxidase, which contributes up to $60 \%$ of the total plasma antioxidant activity in healthy subjects. The study provides data relating serum uric acid, glucose levels and blood hypertension. Seventy nine patients with pregnancy diabetes mellitus, 25 normal healthy with pregnancy, 25 DM patients, and fifty normal healthy persons, where seen from February till July 2017, in AlSemawa General Hospital, were participated in the study. The results revealed a highly significant difference $(P<0.001)$ in uric acid, glucose level and hypertension in almost pregnancy diabetic patients and DM patients when compared to control group. In conclusion, this study found that pregnancy women at the early development stage of glucose disorders had a significantly of hyperuricemia and in clinical practices, measurement of serum uric acid level may help to identify the risk of hypertension.
\end{abstract}

Keywords: uric acid, waste product, xanthine oxidase, plasma antioxidant activity, pregnancy, diabetes mellitus

\section{INTRODUCTION}

Diabetes mellitus (DM) is a group of metabolic diseases characterized by hyperglycemia resulting from defects in insulin secretion, insulin action or both. The chronic hyperglycemia of diabetes is associated with long-term damage and dysfunction of Kidneys, nerves, heart, and blood vessels (1). There are four etiological types of DM: Diabetes mellitus type 1 (DMT1), Diabetes mellitus type 2 (DMT2), other specific types, and gestational diabetes (GDM) that in same way divide to gestational diabetes with impaired tolerance (IGT) and impaired Fasting glucose (IFG) as stages in the natural history of disordered carbohydrates metabolism (2). Gestational diabetes mellitus is a condition in which women without previously diagnosed diabetes exhibit high blood glucose levels during pregnancy (especially during third trimester of pregnancy), and it generally has few symptoms and it is most commonly diagnosed by screening during pregnancy (affects $3-10 \%$ of pregnancies (3). Women with GDM are at increased risk of developing DMT2 (or, very rarely, latent autoimmune diabetes or Type 1) after pregnancy, as well as having a higher incidence of pre-eclampsia and Caesarean section (4). Their offspring are prone to developing childhood obesity, with DMT2 later in life.

Insulin resistance pregnancy hormones and other factors are thought to interfere with the action of insulin as it binds to the insulin receptor (5). Insulin resistance is a normal phenomenon emerging in the second trimester of pregnancy, which progresses thereafter to levels seen in non-pregnant patients with DMT2. It is thought to secure glucose supply to the growing fetus. Women with GDM have an insulin resistance they cannot compensate with increased production in the $\beta$-cells of the pancreas. Placental hormones, and to a lesser extent increased fat deposits during pregnancy, seem to mediate insulin resistance during pregnancy. Cortisol and progesteroneare the main culprits, but human placental lactogen, prolactin and estradiol contribute too (6).

\footnotetext{
1 Dep. of Science, College Basic Education, University of Muthanna, Muthanna, Iraq

2 College of Veterinary Medicine University of Wasit, Wasit, Iraq

3 College of Science, University of Anbar, Al-Anbar, Iraq

4 Pharmaceutical Chemistry Branch, College of Pharmacy, University of Missan, Amarah, Maysan, Iraq
}

Correspondence: Habiba Khudair Abd Al-Sadda

Dep. of Science, College Basic Education, University of Muthanna, Muthanna, Iraq

E-mail:habibakhudair@gmail.com

Received: 13 Mar 2018, Accepted: 26 Jun 2018

(C) 2018 by the authors; licensee Modestum Ltd., UK. This article is an open access article distributed under the terms and conditions of the Creative Commons Attribution License (http://creativecommons.org/licenses/by/4.0/). 
Table 1: Bio statistical calculation for glucose level $\mathrm{mm} / \mathrm{L}$ in serum of GDM patient with different durations and Normal healthy (controls)

\begin{tabular}{|c|c|c|c|}
\hline Glucose $\mathbf{m m} \backslash \mathrm{L}$ & 12> Weeks & 12-24 Weeks & $24<$ Weeks \\
\hline Sample size & 20 & 32 & 27 \\
\hline Mean \pm SD & $10.005 \pm 3.099$ & $13.331 \pm 4.961$ & $15.587 \pm 4.765$ \\
\hline Range & $13.7-6.8$ & $24.1-6.5$ & $26.3-6.7$ \\
\hline SE & 0.693 & 0.877 & 0.917 \\
\hline T- test & \multicolumn{2}{|c|}{2.684} & 4.566 \\
\hline Probability & \multicolumn{2}{|c|}{0.0098 (Significant) } & $<0.0001$ (Highly significant) \\
\hline
\end{tabular}

Hypertensive disorders of pregnancy are the most common medical disorders of pregnancy and are associated with increased maternal and perinatal risks. In a subset of pregnancy women's with gestational hypertension, blood pressure remains elevated after delivery, leading to the diagnosis of chronic hypertension. These women have a tendency not only for hypertension in subsequent pregnancies but for chronic hypertension later in life (7).

Uric acid is a waste product of the living cell, produced by xanthine oxidase, which contributes up to $60 \%$ of the total plasma antioxidant activity in healthy subjects due to its wide distribution and relatively high concentration, and it is more toxic to tissues than either xanthine or hypoxanthine and it released in hypoxic conditions (8). In high concentrations, uric acid may act as a pro - oxidant and hyperuricemia has been suggested to be a risk factor for oxidative stress associated disorders (9). The association of high serum uric acid with insulin resistance has been known since the early part of the 20th century, high serum uric acid as a risk factor for diabetes and the associated with higher risk of DMT2, independent of obesity, dyslipidemia, and hypertension (11).

The aim of this study is to examine and measure potential clinical application of uric acid \&hypertension in the evaluation of pregnancy women with GDM syndrome, and study the possible correlation between serum uric acid with hypertension.

\section{MATERIALS AND METHODS}

\section{Patients Samples}

Seventy nine patients with pregnancy diabetes mellitus, 25 normal healthy with pregnancy, 25 DM patients, and fifty normal healthy person were considered as controls groups, where seen from February till July 2017, in Al-Semawa General Hospital. The diagnosis was done by clinical examination.

\section{Blood Sampling}

The blood was allowed to coagulate at room temperature and centrifuged for $10 \mathrm{~min}$. The resulting serum were separated. The serums were stored at $-20^{\circ} \mathrm{C}$. The stability studies showed that the following parameters (Glucose, Uric acid) were constant under these conditions, for up to three months (10). Blood pressure is measured using a device called asphygmomanometer; this apparatus measures the pressure in the machine's cuff when it's inflated.

\section{Statistical Analysis}

Statistical analysis was done by using student t-test. All the data were presented as mean \pm standard deviation. Pvalues $<0.05$ were considered significant.

\section{RESULTS}

Table 1 depicts all the biochemical parameters which used in this study in patients of DM and control group. There is a highly significant increase in glucose level in pregnancy diabetic patients and DM patients with duration of the pregnant less than 12, between $12-24$ and more than 24 weeks as compared to the control group $(P<0.0001)$. There is no significant correlation between glucose levels in pregnancy diabetic patient with duration of the pregnant between 12-24 weeks \& patients with duration of the pregnant more than 24 weeks as shown in Table 2. 
Table 2: Biostatistical calculation and study $t$-test for glucose level $\mathrm{mm} / \mathrm{L}$ in serum of GDM patients that have duration(1224 weeks) and ( $24<$ weeks) compared with GDM ( $<12$ weeks)

\begin{tabular}{|c|c|c|c|c|}
\hline Glucose $\mathrm{mm} \backslash \mathrm{L}$ & Controls & 12> Weeks & 12-24 Weeks & $24<$ Weeks \\
\hline Sample size & 50 & 20 & 32 & 27 \\
\hline Mean \pm SD & $4.954 \pm 0.911$ & $10.005 \pm 3.099$ & $13.331 \pm 4.961$ & $15.587 \pm 4.765$ \\
\hline Range & $6.1-3.4$ & $13.7-6.8$ & $24.1-6.5$ & $26.3-6.7$ \\
\hline SE & 0.129 & 0.693 & 0.877 & 0.917 \\
\hline T- test & & & 11.674 & 15.349 \\
\hline Probability & \multicolumn{4}{|c|}{$<0.0001$ (Highly significant) } \\
\hline
\end{tabular}

Table 3: Bio statistical calculation for Uric acid level $\mathrm{nm} / \mathrm{L}$ in serum of GDM patient with different durations and Normal healthy (controls)

\begin{tabular}{|c|c|c|c|}
\hline Uric Acid un/L & $12>$ Weeks & 12-24 Weeks & $24<$ Weeks \\
\hline Sample size & 20 & 32 & 27 \\
\hline Mean \pm SD & $276.95 \pm 87.467$ & $359.187 \pm 75.006$ & $404.814 \pm 81.085$ \\
\hline Range & $188-451$ & $199-447$ & $456-220$ \\
\hline SE & 19.558 & 13.259 & 15.604 \\
\hline T- test & \multicolumn{2}{|c|}{3.608} & 5.170 \\
\hline Probability & \multicolumn{2}{|c|}{0.0007 (Significant) } & $<0.0001$ (Highly significant) \\
\hline
\end{tabular}

Table 4: Biostatistical calculation and study $t$-test for Uric acid level un/L in serum of GDM patients that have duration(1224 weeks) and ( $24<$ weeks) compared with GDM (<12 weeks)

\begin{tabular}{|c|c|c|c|c|}
\hline $\begin{array}{l}\text { Uric Acid } \\
\text { un/L }\end{array}$ & Controls & $12>$ Weeks & 12-24 Weeks & $24<$ Weeks \\
\hline Sample size & 50 & 20 & 32 & 27 \\
\hline Mean \pm SD & $343.56 \pm 71.248$ & $276.95 \pm 87.467$ & $359.187 \pm 75.006$ & $404.814 \pm 81.085$ \\
\hline Range & $436-201$ & $188-451$ & $199-447$ & $456-220$ \\
\hline SE & 10.076 & 19.558 & 13.259 & 15.604 \\
\hline T - test & \multicolumn{2}{|c|}{3.307} & 0.949 & 3.429 \\
\hline Probability & \multicolumn{2}{|c|}{0.0015 (Significant) } & 0.3454 (No Significant) & 0.0010(Significant) \\
\hline
\end{tabular}

Table 5: The statistical calculation and students t-test for hypertension level of GDM with all duration of study and Uric Acid levels

\begin{tabular}{|c|c|c|c|c|}
\hline $\begin{array}{l}\text { Uric Acid Un/L } \\
\text { Hypertation\& }\end{array}$ & Hypertation < 12 Weeks & $<12$ Weeks Uric Acid & 12-24 Weeks Uric Acid & $>24$ Weeks Uric Acid \\
\hline Sample size & 8 & 20 & 32 & 27 \\
\hline Mean \pm SD & $13.125 \pm 0.353$ & $276.95 \pm 87.467$ & $359.187 \pm 75.006$ & $404.814 \pm 81.085$ \\
\hline Range & $13-14$ & $188-451$ & $199-447$ & $456-220$ \\
\hline SE & 0.125 & 19.558 & 13.259 & 15.604 \\
\hline$T$ - test & \multicolumn{2}{|c|}{8.434} & 12.923 & 13.520 \\
\hline Probability & \multicolumn{2}{|c|}{$\begin{array}{c}<0.0001 \\
\text { (Highly significant) }\end{array}$} & $\begin{array}{c}<0.0001 \\
\text { (Highly significant) }\end{array}$ & $\begin{array}{c}<0.0001 \\
\text { (Highly significant) }\end{array}$ \\
\hline
\end{tabular}

Table 3 shows that there is a significant increase in Uric Acid level in GDM patients with duration of the pregnant less than 12 weeks and more than 24 weeks as compared to the control. There is no significant difference between patients with duration of the pregnant between 12-24 weeks as compared to the control group. Also there is a significant difference between patients with duration of the pregnant less than 12 weeks \& patients with duration of the pregnant between $12-24$ weeks and patients with duration of the pregnant more than 24 weeks. There is a significant correlation between Uric Acid levels in GDM patient with duration of the pregnant between 12-24 weeks \& patients with duration of the pregnant more than 24 weeks.

In Table 5, there is a highly significant increase in hypertension and Uric Acid levels in GDM patients with duration of the pregnant less than 12 weeks as compared to the control group $(P<0.0001)$, and in GDM with duration of the pregnant between 12-24 weeks there is a significant difference between DM patients $\&$ control group and a significant difference between GDM with duration of the pregnant more than 24 weeks \& control group as shown in table 6 . There is a highly significant difference between hypertension level of patients with different durations of the pregnant \& Uric Acid levels, Table 7 and 8. 
Table 6: The statistical calculation and students t-test for Hypertension level of GDM patient with duration (<12 weeks) and Uric Acid levels of GDM patients with different durations

\begin{tabular}{|c|c|c|c|c|}
\hline $\begin{array}{l}\text { Uric Acid un/L \& } \\
\text { Hypertension }\end{array}$ & Controls Uric Acid & $\begin{array}{c}\text { Hypertension }<12 \\
\text { Weeks }\end{array}$ & $\begin{array}{c}\text { Hypertension } \\
12-24 \text { Weeks }\end{array}$ & Hypertension >24 Weeks \\
\hline Sample size & 50 & 8 & 24 & 20 \\
\hline Mean \pm SD & $343.56 \pm 71.248$ & $13.125 \pm 0.353$ & $13.083 \pm 0.282$ & $13.2 \pm 0.410$ \\
\hline Range & $436-201$ & $13-14$ & $13-14$ & $13-14$ \\
\hline SE & 10.076 & 0.125 & 0.057 & 0.091 \\
\hline T-test & \multicolumn{2}{|c|}{13.020} & 22.642 & 20.645 \\
\hline Probability & \multicolumn{2}{|c|}{$\begin{array}{c}<0.0001 \\
\text { (Highly significant) }\end{array}$} & $\begin{array}{c}<0.0001 \\
\text { (Highly significant }\end{array}$ & $\begin{array}{c}<0.0001 \\
\text { (Highly significant) }\end{array}$ \\
\hline
\end{tabular}

Table 7: The statistical calculation and students $t$-test for Hypertension level of GDM patient with duration (12-24 weeks) and Uric Acid levels of GDM patients with different durations

\begin{tabular}{|c|c|c|c|c|}
\hline $\begin{array}{l}\text { Uric Acid Un/L\& } \\
\text { Hypertation }\end{array}$ & $\begin{array}{c}\text { >24 Weeks } \\
\text { Hypertension }\end{array}$ & $<12$ Weeks Uric Acid & 12-24 Weeks Uric Acid & >24 Weeks Uric Acid \\
\hline Sample size & 20 & 20 & 32 & 27 \\
\hline Mean \pm SD & $13.2 \pm 0.410$ & $276.95 \pm 87.467$ & $359.187 \pm 75.006$ & $404.814 \pm 81.085$ \\
\hline Range & $13-14$ & $188-451$ & $199-447$ & $456-220$ \\
\hline SE & 0.091 & 19.558 & 13.259 & 15.604 \\
\hline$T$ - test & \multicolumn{2}{|c|}{13.485} & 20.552 & 21.537 \\
\hline Probability & \multicolumn{2}{|c|}{$\begin{array}{c}<0.0001 \\
\text { (Highly significant) }\end{array}$} & $\begin{array}{c}<0.0001 \\
\text { (Highly significant) }\end{array}$ & $\begin{array}{c}<0.0001 \\
\text { (Highly significant) }\end{array}$ \\
\hline
\end{tabular}

Table 8: The statistical calculation and students t-test for Hypertension level of GDM patient with duration (>24 weeks) and Uric Acid levels of GDM patients with different durations

\begin{tabular}{|c|c|c|c|c|}
\hline $\begin{array}{l}\text { Uric Acid Un/L Hypertation } \\
\&\end{array}$ & Hypertation 12-24 Weeks & $<12$ Weeks Uric Acid & $\begin{array}{l}\text { 12-24 Weeks } \\
\text { Uric Acid }\end{array}$ & >24 Weeks Uric Acid \\
\hline Sample size & 24 & 20 & 32 & 27 \\
\hline Mean \pm SD & $13.08333 \pm 0.2823299$ & $276.95 \pm 87.46758$ & $359.1875 \pm 75.00642$ & $404.8148 \pm 81.08544$ \\
\hline Range & $13-14$ & $188-451$ & $199-447$ & $456-220$ \\
\hline Standard error of mean & 0.05763034 & 19.55834 & 13.25939 & 15.6049 \\
\hline T - test & \multicolumn{2}{|c|}{14.814} & 22.553 & 23.641 \\
\hline Probability & \multicolumn{2}{|c|}{$\begin{array}{c}<0.0001 \\
\text { (Highly significant) }\end{array}$} & & $\begin{array}{c}<0.0001 \\
\text { (Highly significant) }\end{array}$ \\
\hline
\end{tabular}

\section{DISCUSSION}

The untimely interference and suitable management in female with GDM will be cooperative in preventing the adverse maternal and prenatal outcome and as well protect them from long term consequences. Several studies have shown the association of hyperuricaemia in the first trimester with development of GDM later in life. In current study, Uric acid levels in serum of GDM patients that have different durations in pregnancy seemed to be significantly differences $(P<0.01)$, this results suggested that increased serum uric acid (a physiological antioxidant) in early trimester was associated with higher incidence of GDM. This finding is in accordance with that of Fawzy et al. (11), El-Gharib et al. (22), Aparna K et al. (13), Sujata Maitra et al. (15), Nagalkshmi CS et al. (16), Talya Wolak et al. (19) and Zhou J et al. (2012) who demonstrated that the first trimester hyperuricemia is associated with an increased risk of developing GDM. The elevation in serum uric acid level may be a protective response which is capable of opposing harmful effects of free radical and oxidative stress seen in GDM as uric acid possesses antioxidant properties, and contributes about $60 \%$ of free radical scavenging activity in human serum. Elevated serum uric acid can predict the development of diabetes and hence can be considered as an early sign of peripheral insulin resistance syndrome. Elevated or high normal levels of serum uric acid in first trimester may be associated with a preexisting metabolic derangements which lead to poor maternal physiological adaptations and predisposes the pregnant women to development of pregnancy complication like GDM (14).

The finding results were consistent with Yoo et al. (23), when they found in a huge cross-sectional study of 53.477 non-pregnant females, that serum uric acid was positively correlated with fasting serum glucose and insulin resistance, as well as features of the metabolic syndrome, including hypertension and fasting glucose. 
Hypertensive disturbances are the most common medical disorders of pregnancy and are associated with increased maternal and perinatal risks. In this study we observed the strong positive association between hyperuricemia and hypertension. There was a highly significant difference $(P<0.0001)$ in hypertension level of GDM patient and uric acid levels with different durations. Garrick et al. (25) found that 31\% of their patients had hyperuricemia with hypertension. Significant high serum uric acid level in hypertensive patients were also observed by Eisen et al. (26) and Grayson et al. (27). The serum level of uric acid was associated with the incident of hypertension and may be important of developing hypertension (24).

In conclusion, we found that pregnancy women at the early development stage of glucose disorders had a significantly of hyperuricemia and in clinical practices, measurement of serum uric acid level may help to identify the risk of hypertension.

\section{REFERENCES}

1. Silverthorn D. Human physiology-Person International Edition. An Integrated Approach, $5^{\text {th }}$ ed., 2010;Ch 22:7427.

2. Diagnosis and Classification of Diabetes Mellitus. American Diabetes Association.2013;36(1).

3. Mohamed MS, Zahran KM, Mohamed HS, Galal H, Mustafa AM. Pattern of glucose intolerance among pregnant women with unexplained IUFD. Middle East Fertility Society Journal. 2015;20(1)1: 43-7.

4. Donovan, PJ. Drugs for gestational diabetes. Australian Prescriber. 2010;(33):141-4. https://doi.org/10.18773/austprescr.2010.066

5. Achong N, Mclntyre HD, Callaway L. Factors determining insulin requirements in women with type 1 diabetes mellitus during pregnancy: a review. Obstet Med. 2014;7(2):52-9. https://doi.org/10.1177/1753495X13516442 PMid:27512424 PMCid:PMC4934947

6. Sonagra AD, Biradar SM, Dattatreya K, Jayaprakash MD. Normal Pregnancy-A State of Insulin Resistance J Clin Diagn Res. 2014;8(11):CC01-CC03. PMid:25584208

7. Garovic VD, August Ph. Preeclampsia and the Future Risk of Hypertension: The Pregnant Evidence, Curr Hypertens Rep. 2013;15(2):1-14. https://doi.org/10.1007/s11906-013-0329-4 PMid:23397213 PMCid:PMC3812434

8. Dehghan A, van HM, Sijbrands EJ, Hofman A, Witteman JC. High serum uric acid as a novel risk factor for type 2 diabetes. Diabetes Care. 2008;31(2):361-2. https://doi.org/10.2337/dc07-1276 PMid:17977935

9. Baillie JK, Bates MG, Thompson AA, Waring WS, Partridge RW, Schnopp MF, Simpson A, Gulliver - Sloan F, Maxwell SR, Webb DJ. Endogenous urate production augments plasma antioxidant capacity in healthy lowland subjects exposed to high altitude. Chest. 2007;131(5):1473-8. https://doi.org/10.1378/chest.06-2235 PMid: 17494796

10. Ramanavicius A. Amperometric biosensor for the determination of creatine. Anal. Bioanal. Chem. 2007;387:1899906. https://doi.org/10.1007/s00216-006-1065-2 PMid:17221239

11. Fawzy MM, Mohamed MEM, Hassanin AS, Ghally MN. The Association between Hyperuricemia in First Trimester and the Development of Gestational Diabetes; JFIV Reprod Med Genet. 2017;5(2):1-8.

12. Laughon SK, Catov J, Provins T, Roberts JM, Gandley RE. Elevated first-trimester uric acid concentrations are associated with the development of gestational diabetes. Am J Obstet Gynecol. 2009;201:402.e1-5. https://doi.org/10.1016/j.ajog.2009.06.065

13. Aparna K. Increased uric acid and GDM occurrence. International Journal of Dental and Medical Science. 2013;13.

14. Amudha $P$, Nithya $D$, Pradeeba $S$, Manochithra B. Correlation between first trimester uric acid level and subsequent development of gestational diabetes mellitus. Int J Reprod Contracept Obstet Gynecol. 2017;6(2): 606-10. https://doi.org/10.18203/2320-1770.ijrcog20170391

15. Maitra S, Anitha M, Praveen S, Suresh SK, Vishwanath HL. A Study of Oxidative Stress in Gestational Diabetes Mellitus: An Observational Study at a Tertiary Centre. Asian J Med Res. 2012;1(1):17-21.

16. Nagalaksmi CS, Devaki RN, Akila P, Suma KB, Prashant V, Suma MN. Exploration of the Clinico- Biochemical Parameters to Explain the Altered Renal Mechanisms in Gestational Diabetes Mellitus. J Clin Diagn Res. 2012;6(3):369-71.

17. Kharb S. Uric Acid and Ascorbic Acid Levels in Pregnancy with Preeclampsia and Diabetes. Webmed Central Biochemistry. 2010;1(10). 
18. Laughon SK, Catovr J, Provins T, Roberts JM, Gandley RE (2009). Elevated first trimester uric acid concentrations are associated with the development of gestational diabetes. Am J Obstet Gynecol.; 201(4):402e1-e5.

19. Wolak T, Sergienko R, Wiznitzer A, Paran E, Sheiner E. High Uric Acid Level during the First 20 Weeks of Pregnancy is Associated with Higher Risk for Gestational Diabetes Mellitus and Mild Preeclampsia2012. Hypertens Pregnancy. 2012;31(3):307-15. https://doi.org/10.3109/10641955.2010.507848 PMid:20822424

20. Zhou J, Zhao X, Wang Z, Hu Y. Combinations of lipids and uric acid in mid-second trimester can be used to predict adverse pregnancy outcomes. J Matern Fetal Neonatal Med. 2012;25(12):2633-8.97.

21. Amol DS, Archana SG, Mangesh T, Sucheta G. Study of serum uric acid and erythrocytic superoxide dismutase levels in gestational diabetes mellitus and normal pregnancy, International Journal of Recent Trends in Science And Technology. 2016;21(1):29-33.

22. El-Gharib MN, Mahfouz AE, Morad MA, Farahat MA. Prediction of Gestational Diabetes by Measuring First Trimester Maternal Serum Uric Acid Concentration. Journal of Basic and Clinical Reproductive Sciences. 2013;(2)1:27-31. https://doi.org/10.4103/2278-960X.112582

23. Yoo TW, Sung KC, Shin HS, Kim BJ, Kim BS, Kang JH. Relationship between serum uric acid concentration and insulin resistance and metabolic syndrome. Circ J. 2005;69:928-33. https://doi.org/10.1253/circj.69.928 PMid:16041161

24. Bibek $P$, Binod $K Y$, Arun $K$, Bharat J, Kanak BR. Serum uric acid level in newly diagnosed essential hypertension in a Nepalese population: A hospital based cross sectional study. Asian Pac J Trop Biomed. 2014;4(1):59-64. https://doi.org/10.1016/S2221-1691(14)60209-4

25. Garrick Bauer RGE, Ewan CE, Neale FC. Serum uric acid in normal and hypertensive Australian subjects: from a continuing epidemiological survey on hypertension commenced in 1955. Internal Med J. 2008;2:351-356.

26. Eisen A, Benderly $M$, Goldbourt U, Haim M. Is serum uric acid level an independent predictor of heart failure among patients with coronary artery disease? Clin Cardiol. 2013;36:110-6. https://doi.org/10.1002/clc.22083 PMid:23335377

27. Grayson PC, Kim SY, LaValley M, Choi HK. Hyperuricemia and incident hypertension: a systematic review and meta-analysis. Arthritis Care Res (Hoboken). 2011;63:102-110. https://doi.org/10.1002/acr.20344 PMid:20824805 PMCid:PMC3016454

$\diamond \diamond \diamond \diamond \diamond \diamond \diamond$

http://www.ejgm.co.uk 